\title{
Working
}

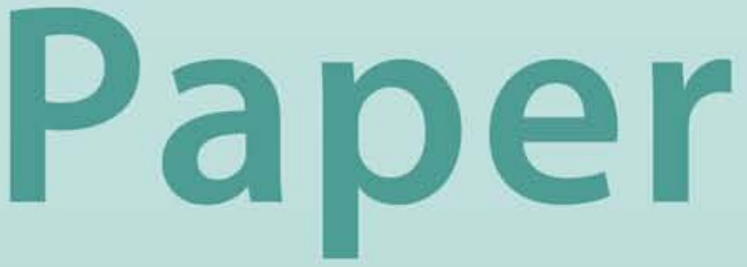




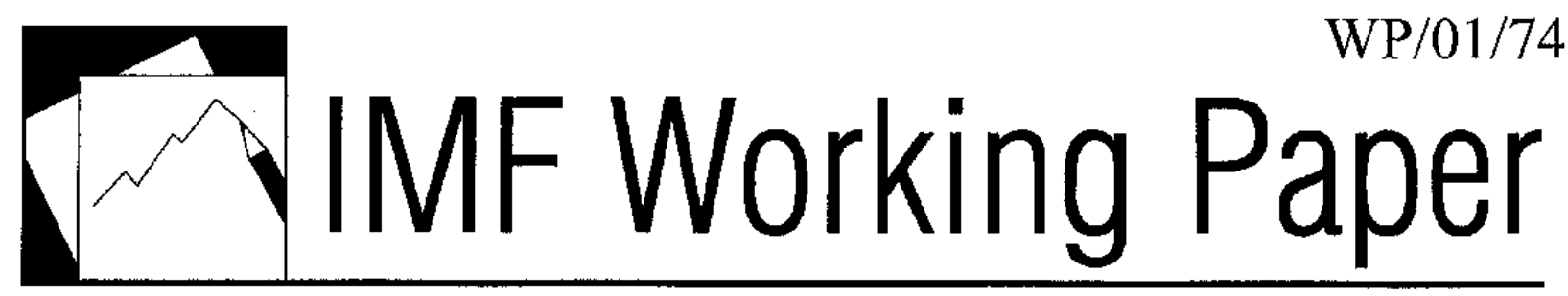

Fiscal Deficits and Inflation: A New Look at the Emerging Market Evidence

\author{
Luis Catão and Marco Terrones
}




\title{
IMF Working Paper
}

\author{
Research Department
}

\section{Fiscal Deficits and Inflation: A New Look at the Emerging Market Evidence}

\author{
Prepared by Luis Catão and Marco Terrones ${ }^{1}$ \\ Authorized for distribution by Tamim Bayoumi
}

May 2001

\begin{abstract}
The views expressed in this Working Paper are those of the author(s) and do not necessarily represent those of the IMF or IMF policy. Working Papers describe research in progress by the author(s) and are published to elicit comments and to further debate.
\end{abstract}

Empirical studies have had little success in finding a statistically significant relationship between fiscal deficits and inflation in broad cross-country panels. This paper provides new econometric estimates for a panel of 23 emerging market countries during 1970-2000. Unlike previous studies, we allow for a rich dynamic specification and focus on the long-run relationship between the two variables controlling for differences in the inflation tax base. We find that a 1 percentage point reduction in the ratio of fiscal deficit to GDP typically lowers long-run inflation by $1 \frac{1 / 2}{2}$ to 6 percentage points, depending on the size of the inflation tax base.

JEL Classification Numbers: E31, E60

Keywords: Fiscal Policy, Inflation, Emerging Markets.

Authors’ E-Mail Addresses: 1catao@imf.org, mterrones@imf.org

\footnotetext{
${ }^{1}$ We thank Tam Bayoumi, Peter Clark, Hali Edison, Ken Kletzer, David Robinson, and participants of a seminar in the IMF research department for comments on this draft, Ben Sutton for able research assistance, and Marlene George for assistance with the preparation of this paper.
} 


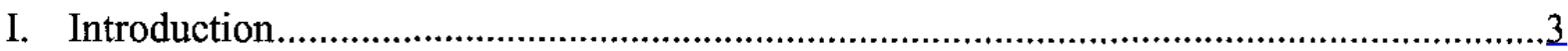

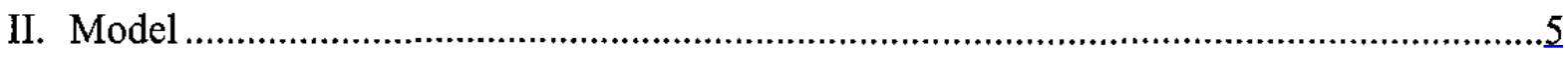

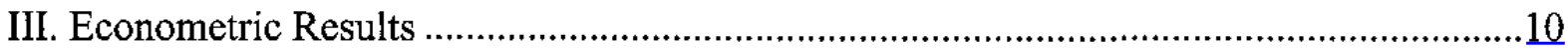

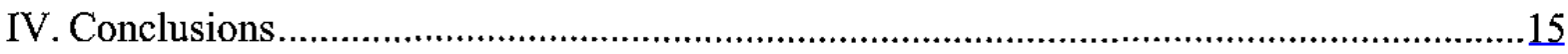

\section{Text Tables}

1. Inflation in Developed Countries and Emerging Markets. ....................................18

2. Emerging Market Countries: Selected Variables.................................................19

3. Estimates of Inflation on Government Deficit..................................................20

4. Estimates of Inflation on government Deficit, Oil Prices, and World Inflation ..........21

5. Estimates of Inflation on Openness, Oil Prices, World Inflation, and Government Deficits................................................................................... 22

6. Estimates of Inflation on Government Deficit, Oil Prices, World Inflation,

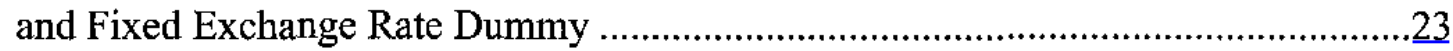

7. Estimates of Inflation on Government Deficit, Oil Prices, and World Inflation, excluding countries that experienced hyperinflation ........................................... 24

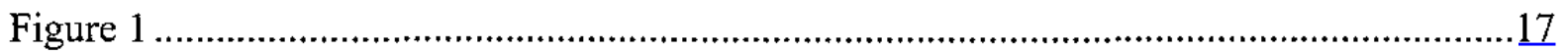

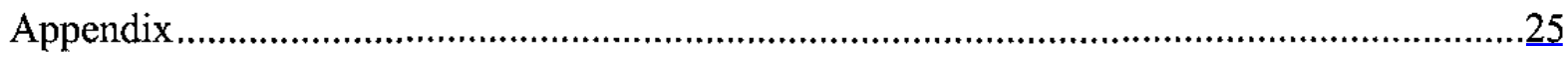

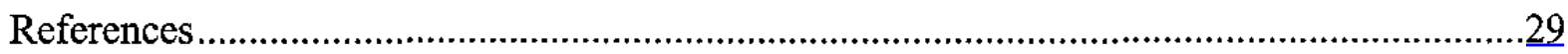


"A common criticism of this stress on the budget deficit is that the data rarely shows a strong positive association between the size of the budget deficit and the inflation rate."

(Blanchard and Fischer, 1989, p.513)

\section{INTRODUCTION}

From coin clipping in Ancient Rome to the printing of inconvertible paper money to finance modern wars, history has often witnessed governments' resort to seignorage at times of fiscal distress. It should therefore come as no surprise that much of the contemporary macroeconomics literature has focused on fiscal behavior when trying to explain why inflation has varied so widely, both across countries and over time, in recent decades. Following Sargent and Wallace's (1981) seminal contribution, a well-established view is that fiscally dominant governments running persistent deficits have sooner or later to finance those deficits with money creation, producing inflation. While subsequent research has highlighted a number of other mechanisms through which inflation can be fuelled and may become highly persistent, fiscal imbalances have remained at the center stage of most theoretical models. ${ }^{2}$ Fiscal-based theories of inflation have been especially prominent in the developing country literature, where it has long been recognized that less efficient tax collection, political instability, and more limited access to external borrowing tend to lower the relative cost of seignorage in these countries, increasing their dependence on the inflation tax and delaying macroeconomic stabilization (Alesina and Drazen, 1991; Cukierman, Edwards, and Tabellini, 1992; Calvo and Végh, 1999).

Yet, econometric work has had little success establishing a statistically significant connection between the fiscal deficits and inflation for a broad range of countries and inflation rates. For instance, King and Plosser's (1985) comprehensive analysis of the determinants of seignorage in the United States and twelve other countries, using both single equation OLS regressions and VARs, find no significant causality running from fiscal deficits to changes in base money and inflation. In a more restricted sample consisting of few high inflation emerging markets, and using Granger-causality tests and variance decompositions in VAR framework, Montiel (1989) and Dornbusch, Sturzenegger, and Wolf (1990) find little support for the fiscal view, suggesting instead that exchange rate shocks have been the main driving force behind inflation. More recently, Fisher, Sahay, and Végh (2000) using a very broad cross-country panel and fixed effect estimates have indicated that fiscal deficits have been a determinant of high inflations (defined in excess of 100 percent a year); however, they find no evidence of a significant relationship between inflation and

${ }^{2}$ See Ljungqvist and Sargent (2000), and Fischer, Sahay, and Végh (2000) for recent surveys. 
fiscal balances for low inflation countries, or during low inflation periods in the high inflation countries. At the other extreme of the literature, some studies have not even included the fiscal balance as a possible explanatory variable of inflation and seignorage (e.g. Romer, 1993; Lane, 1995; Campillo and Miron, 1997; Click, 1998). ${ }^{3}$

This paper takes a new look at the issue. Relative to previous studies, its empirical approach has three main novelties. First, it focuses on the experience of emerging market economies (EMs henceforth). ${ }^{4}$ One reason for limiting our attention to EMs is that the largest swings in inflation rates during the post-World War II period have taken place among this group of countries. As Figure and Table 1 show, following a gradual rise from the $1950 \mathrm{~s}$ and a sharp acceleration through the 1980s, consumer price inflation in EMs has fallen sharply during the 1990s and is currently approaching advanced country levels; meanwhile, the dispersion of inflation rates across the distinct EM regions has been greatly reduced. And yet, there is scant systematic evidence on what caused such dramatic trend shifts. Another reason for restricting our attention to EMs is that this arguably provides us with a less heterogeneous panel in terms of data quality and degree of fiscal dominance. To the extent that such a panel is less "noisy" than those which pool low-, middle-, and high-income countries together, the chance of detecting statistically significant relationships in the data is enhanced.

Second, this paper uses an econometric specification explicitly derived from an intertemporal optimization model that relates long-run inflation to the permanent component of the fiscal deficit, where the latter is scaled by the size of the inflation tax base (measured by the ratio of narrow money to GDP). The use of this scaling variable distinguishes our econometric specification from that found in most studies, which scale the relevant fiscal variable by nominal GDP. As discussed below, the use of narrow money as a scaling variable is not only theoretically and intuitively appealing, but also introduces a desired non-linearity in the relationship between the fiscal deficits (scaled by GDP) and inflation. Such a nonlinearity seems to accord well with stylized facts about inflation dynamics and is shown to have clear microfoundations.

${ }^{3}$ To be precise, Campillo and Miron (1997) include government debt/GDP ratio at a base year in their regressions, but no time series on deficits or any other fiscal variable. Click (1998) regresses government spending to GDP on a measure of seignorage and finds that government spending is not a determinant of cross-country differences in seignorage.

${ }^{4}$ For the purpose of this paper, the following countries are defined as emerging markets: Argentina, Brazil, Chile, China, Colombia, Egypt, Hungary, India, Indonesia, Israel, Korea, Malaysia, Mexico, Morocco, Pakistan, Peru, Philippines, South Africa, Thailand, Turkey, Uruguay, Venezuela, and Zimbabwe. This sample excludes three countries usually classified as emerging markets (Czech Republic, Poland, and Russia) due to data limitations. At the same time, it includes two countries (Morocco and Zimbabwe) which have lower nominal GDP than other countries typically classified as emerging markets, in an effort to broaden geographical coverage. 
Third, a main novelty of this paper in the context of the inflation literature is the use of a dynamic panel approach that explicitly separates short-run adjustment dynamics from long-run equilibrium relationships. When it comes to the relationship between fiscal deficit and inflation such a distinction is crucial. This is because fiscal deficits need not lead to higher seignorage in the short-run, since governments can temporarily finance budget deficits with borrowing. Thus, the main focus of the analysis should be on the longer-term parameters underlying this relationship and the speed of adjustment to the long-run equilibrium (if it exists). This paper estimates the strength and statistical significance of the long-run relationship between the fiscal deficit and inflation in a dynamic panel setting using the "pooled mean group estimator" (PMGE henceforth) recently advanced by Pesaran, Shin, and Smith (1999). As discussed in detail later on, a key advantage of the PMGE relative to the fixed effects estimator widely used in the literature is that of leaving unspecified the coefficients on the short-run relationship between the variables (thus being better suited to accommodate the complex short-run dynamics of inflationary processes), while allowing the researcher to impose and test the long-run restrictions predicated by theory cross-sectionally.

The remainder of this paper is organized as follows. Section 2 lays out the econometric model and discusses the various issues involved in its estimation. Section 3 reports the respective results. Section 4 concludes with a summary of the main findings and a discussion of their policy implications. A detailed derivation of the theoretical model underlying the econometric analysis is provided in the Appendix.

\section{THE MODEL}

A central point of Sargent and Wallace (1981) is that the relationship between fiscal deficit and inflation is dynamic. Under fiscal dominance, deficits determine the present value of seignorage but not necessarily current seignorage. This is because borrowing allows governments to allocate seignorage intertemporally, implying that fiscal deficits and resort to the inflation tax need not be contemporaneously correlated. Indeed, the short-run dynamics of the fiscal deficit-inflation relationship is often very complex, partly because of feedback effects of inflation on the fiscal balance. ${ }^{5}$ As a result, the direction and proximate rnagnitude

${ }^{5}$ For a discussion of these feedback effects, see Dornbusch, Sturzenegger, and Wolf (1990). Specifically, the literature has highlighted six mechanisms through which inflation may affect the ratio of fiscal deficit to GDP: (i) lags in tax collection, which reduce the real value of the latter as inflation rises (the "Tanzi effect"); (ii) lower tax compliance as inflation rises (reflecting, inter alia, diminished credibility in public institutions); (iii) the burden of taxation rises, partly because households move into higher tax brackets in a progressive and less than perfectly indexed tax system; (iv) time lags between budgeted and actual government disbursements help reduce the real value of public spending; (v) the real value of the public debt may be eroded by inflation under imperfect indexation, but real interest 
of the net short-run effect cannot be typically predicted a priori by theoretical considerations alone.

In contrast, the long-run relationship between the two variables is clearly spelled out by theory. This is shown in the Appendix, which lays out a simple general equilibrium model relating fiscal deficits, the supply and demand for money, and inflation. The model is in the spirit of Sargent and Wallace in that fiscal policy is exogenously determined (fiscal dominance) but, unlike theirs, has explicit microfoundations derived from a shopping time dynamic model along the lines of Ljungqvist and Sargent (2000), which we have extended to an open economy setting. Such a model yields a simple functional form in steady state equilibrium, postulating that inflation is positively and linearly related to the fiscal deficit scaled by narrow money:

$$
\pi=\beta\left[\frac{G-T}{M 1}\right]
$$

where G-T stands for the nominal budget deficit (including interest payments), $M 1$ is the stock of narrow money, and $\beta$ is a positive parameter. Dividing the numerator and the denominator of (1) by GDP yields the conventional measures of the fiscal deficit and of the size of the inflation tax base, respectively. Equation (1) constitutes the backbone of the econometric specification used in this paper.

The postulated model has two key features that distinguish it from others considered in the literature. ${ }^{6}$ First, since the fiscal deficit is scaled by the stock of narrow money, inflation will rise (fall) once the ratio of fiscal deficit to GDP widens (shrinks), or the ratio of narrow money to GDP shrinks (expands), or as a result of a combination of the two. Second, because the demand for money is a negative function of inflation, the size of the inflation tax base will be lower (higher) as inflation is higher (lower). Hence, changes in the fiscal balance will affect inflation in a non-linear fashion: the higher (lower) the inflation rate, the greater (smaller) the impact of a reduction in the fiscal deficit (measured relative to GDP) on

payments may actually rise if real interest rates increase due to bondholders' demand for higher risk premia; (vi) average public sector wages tend to decline even if indexed, provided that their adjustment intervals remain unchanged as inflation rises. As some of these effects clearly offset each other, it is often difficult to predict the net effect of inflation on the deficit.

${ }^{6}$ See, for instance, Cagan (1956) and Dornbusch, Sturzenegger, and Wolf (1990) for specifications wherein the ratio of fiscal deficit to GDP is directly related to inflation without featuring the inflation tax base as a scaling variable. Two studies that include the ratio of narrow money to GDP in regressions relating fiscal deficits to inflation are Rodrik (1991) and Metin (1998). 
inflation. This is because the inflation tax base shrinks with rising inflation, requiring a faster increase in money supply and inflation to finance a given deficit.

We allow for a rich dynamics in the way inflation adjusts to changes in the fiscal deficit or to any other variable, by nesting the postulated theoretical model in an autoregressive distributed lag (ARDL) structure where the dependent and the explanatory variables enter the regression with lags of order $p$ and $q$, respectively: ${ }^{8}$

$$
\pi_{i, t}=\mu_{i}+\sum_{j=1}^{p} \lambda_{i, j} \pi_{i, t-j}+\sum_{j=0}^{q} \delta_{t, j}^{\prime} x_{i, t-j}+\varepsilon_{i, t}
$$

where $\pi_{i, t}$ stands the observed inflation rate in group $i$ at time $\mathrm{t} ; \mu_{i}$ represents fixed effects; and $x_{i, t}$ is a $(\mathrm{kx} 1)$ vector of explanatory variables which includes $(G-T) / M$, i.e, $x_{i, t}=\left[\begin{array}{l}(G-T) / M 1 \\ x_{i, t}^{*}\end{array}\right]$, and $x_{i, t}^{*}$ is a $(k-1,1)$ vector. Equation (2) can be re-parameterized and written in terms of a linear combination of variables in levels and first-differences:

$$
\Delta \pi_{i, t}=\mu_{i}+\phi_{i} \pi_{i, t-1}+\varphi_{i}^{\prime} x_{i, t}+\sum_{j=1}^{p-1} \lambda_{i, j}^{*} \Delta \pi_{i, t-j}+\sum_{j=0}^{q-1} \delta_{i, j}^{* \prime} \Delta x_{i, t-j}+\varepsilon_{i, t}
$$

where $\phi_{i}=-\left(1-\sum_{j=1}^{p} \lambda_{i, j}\right), \quad \varphi_{i}=-\sum_{j=0}^{p} \delta_{i, j}, \quad \lambda_{i, j}^{*}=-\sum_{m=j+1}^{p} \lambda_{i, m}, \quad \delta_{i, j}^{*}=-\sum_{m=j+1}^{q} \delta_{i, m}^{\prime}$, with $j=1,2, \ldots, p-1$.

Grouping the variables in levels, equation (3) be re-written as:

$$
\Delta \pi_{i, t}=\mu_{i}+\phi \phi_{i}\left[\pi_{i, t-1}-\theta_{i} x_{i, t}\right]+\sum_{j=1}^{p-1} \lambda_{i, j}^{*} \Delta \pi_{i, t-j}+\sum_{j=0}^{q-1} \delta_{i, j}^{*} \Delta x_{i, t-j}^{*}+\varepsilon_{i, t}
$$

\footnotetext{
${ }^{7}$ Some studies have attempt to capture this non-linearity by measuring inflation as $\log (1+\pi)$ and regressing it on the nominal fiscal deficit scaled by nominal GDP. The advantage of the specification used in this paper is that such non-linearities are explicitly derived from a model with microfoundations and shown to be related to factors pertaining to the demand for money and domestic financial development.

${ }^{8}$ See Banerjee, Dolado, Galbraith, and Hendry (1993) for an useful survey of ARDL models. Pesaran and Shin (1998) discuss the use of ARDL model in the estimation of cointegrating relationships and show that it has desirable finite sample properties.
} 
where $\theta_{i}=-\frac{\dot{\varphi_{i}}}{\phi_{i}}=\left[\begin{array}{l}\beta_{i} \\ \gamma_{i}\end{array}\right]$ defines the long-run equilibrium relationship between the variables involved, with $\beta_{i}$ being the coefficient on (G-T)/M1 as in (1), and $\phi_{i}$ the speed of adjustment toward the long-run equilibrium.

Pesaran, Shin, and Smith (1999) have advanced a maximum likelihood approach that provides consistent estimates of those parameters in dynamic panels with considerable heterogeneity across the distinct groups, $i$. Their method is specifically devised for large panels (balanced or unbalanced) where the cross-section $(\mathrm{N})$ and time-series $(\mathrm{T}$ ) dimensions of the sample are of the same order of magnitude, but $\mathrm{T}$ is large enough so that (4) can be estimated for each group separately. With 23 countries and 31 years of annual observations (1970-2000), the data set used in this paper clearly meets these requirements.

The approach advanced by Pesaran, Shin, and Smith-the "pooled mean group estimator" (PMGE) — differs in important respects from other estimators commonly used in the panel data literature. Compared with static and dynamic fixed effects (DFE) estimators, the PMGE allows the short-run dynamic specification of the model to vary across countries. In other words, $p$ and $q$ in equation (4) can vary from country to country, and so can the coefficients on the first-differenced variables $\lambda_{i, j}^{*}, \delta_{i, j}^{*}$. This is a clear advantage in the present context because inflation processes of the type observed in some EMs can display a complex short-run dynamics, so short-run coefficients are better left unrestricted as much as possible. Likewise, the PMGE does not constrain error variances to be the same across countries. Allowing for distinct error variances across groups is also advantageous in the context of cross-country analyses of inflation since individual country variances may be quite different, partly reflecting the wide disparities in historical inflation rates illustrated in Figure 1. By leaving intercepts, short-run coefficients, and error variances unconstrained across groups, the PMGE is also better suited to handle outlier observations such as those typically associated with hyperinflations.

Compared to the simple mean group estimator (MG), the PMGE has the attractive feature of allowing us to impose cross-sectionally long-run homogeneity restrictions derived from the theory, when such restrictions take the form of $\beta_{i}=\beta, \gamma_{i}=\gamma, \forall \mathrm{i}=1,2, .$. N.. ${ }^{9}$ The validity of the respective restrictions can be readily tested by Hausman tests on the difference

\footnotetext{
${ }^{9}$ The MG estimator consists of estimating separate ARDL models for each country and obtaining the overall panel estimates as the arithmetic average of individual country coefficients. The MG estimator has been shown to produce consistent estimates of the average of the parameters in heterogeneous panels, but such estimates will be inefficient if slope homogeneity restrictions hold.
} 
between the PMGE and the MG estimates. In situations where those cross-equation restrictions cannot be rejected, the PMGE produces more efficient estimates. Pesaran, Shin, and Smith (1999) show that such efficiency gains can be very large in small samples, so the PMGE should be clearly preferred in those situations.

Two main issues arise in the estimation of (4). One issue is the inclusion is the stationarity or order of integration of the variables involved and whether the respective longterm relationships are correctly estimated for all possible combinations of variables with different orders of integration. Pesaran and Shin (1998) have shown that if there is a unique vector defining the long-run relationship among the variables involved, the ARDL specification yields consistent estimates of that vector-no matter whether the variables involved are $I(1)$ or $I(0)$-provided that the lag structure (as defined by $p$ and $q$ ) is suitably chosen. In these circumstances, the estimated t-ratios can be given a classical interpretation, allowing us to undertake the standard significance tests. A major advantage of the ARDL specification in this case is to dispense with the pre-testing of the variables for unit roots - a procedure which is marred by the lower power of unit root tests and the controversy about their small sample properties in panels (see, e.g., O'Connell, 1998). The question is then whether we can safely assume that there exists just one vector tying up the variables in the long-run. In a bivariate case, the issue is simpler but it can become very controversial in a multivariate context. In those circumstances, Pesaran (1997) makes a strong case for the use of economic theory in taking a stand on the matter. In our case, the underlying theoretical model postulates the existence of just one vector tying fiscal deficits, narrow money, and inflation in the long-run. We work with this premise through the remainder of this paper.

A related econometric issue is causality. The existence of a long-run equilibrium vector does not necessarily imply that the right-hand side variables "cause" the left-hand side variable in (4). If the variables are $\mathrm{I}(1)$ and cointegrated, the statistical property of superconsistency ensures that endogeneity biases will vanish as $\mathrm{T}$ tends to infinity. But if $\pi,(G-T) / M 1$, and $x$, are all $\mathrm{I}(0)$, the endogeneity issue may be critical, since both the ratios of the fiscal deficit to GDP (particularly its nominal interest payment component) and the size of the inflation tax base (M1/GDP) tend to be affected by inflation. ${ }^{10}$ Although it can be argued that the feedback effects of inflation on these variables are likely to be weaker in the long-run, the robustness of the results to potential endogeneity biases should be tested. One way is to instrument the $(G-T) / M 1$ variable using its lagged values. The problem with this procedure is that lagged values of $(G-T) / M 1$ may be a very bad instrument for current changes in the stance of fiscal policy. ${ }^{11}$ One alternative is to use a deficit measure that is less

${ }^{10}$ With regard to other explanatory variables we consider, such as world inflation and oil prices, the exogeneity assumption seems clearly warranted.

${ }^{11}$ This was case for several countries in the sample. Regressing current values of $(G-T) / M 1$ on its lags as well as on lagged inflation yielded $R^{2}$ 's below 0.5 in quite a few cases. 
influenced by the inflation component of nominal interest rate payments, such as the operational deficit concept or, even more stringently, the primary deficit. ${ }^{12}$ Another alternative is to check the sensitivity of the coefficient on $(G-T) / M 1$ to the exclusion from the sample of countries that experienced long-periods of high inflation and bouts of hyperinflation, since it is precisely in those circumstances when the fiscal deficit have been shown to become highly endogenous (see, e.g., Sargent, 1982; Franco, 1990). Due to data limitations, it was not possible to obtain sufficiently long data series on the operational deficit measure for most EM countries. We did experiment, however, with the primary deficit measure and the exclusion of high and hyperinflation inflation countries from the sample. The results are reported below.

\section{ECONOMETRIC RESULTS}

The null hypothesis we seek to test is that there exists no long run relation between government deficits and inflation. As discussed above, the main econometric technique we use is the PMGE. However, MG and heteroscedasticity-corrected fixed effects estimates are also reported, both to evaluate the robustness of the results to the use of different methods and permit comparability with other studies. Among other things, this should help answer the question of whether the failure of other studies in detecting a significant relationship between fiscal deficits and inflation are due to differences in econometric techniques, in model specification, or sampling.

The data set spans 23 countries and 31 years over 1970-2000, for a total of 656 observations. ${ }^{13}$ Data sources are the IMF's Government Financial Statistics, the International Financial Statistics, and the World Economic Outlook database, with the sole exception of the series on China's fiscal deficit which was obtained from the Asian Development Bank. Unless otherwise noted, the dependent variable is the percent change of consumer price inflation. Money stock for any given year is measured as the arithmetic average of that year's end-December stock and the preceding year's end-December stock of domestic M1 (i.e., excluding foreign-currency denominated deposits). The main fiscal deficit measure is the nominal deficit of the central government, including transfers and net interest payments. ${ }^{14}$

${ }^{12}$ See Tanzi, Blejer, and Teijero (1993) and Atiyas et al. (1999) for the concept and measurement of the operational deficit measure.

${ }^{13}$ Observations for two countries (China and Hungary) only start from 1980 and a few others from the mid-1970s. So, the panel is unbalanced.

${ }^{14}$ Long series on broader fiscal deficit measures comprising local governments and including central bank losses proved impossible to obtain on a consistent basis for all countries. While the distinction is relatively unimportant for countries where the fiscal system is highly centralized (most Asian countries), level differences between central and general government deficits have been substantial in some cases (notably in Latin America). Yet, an inspection of data for some fiscally decentralized countries for which both measures are available indicates 
However, as discussed above, we also report results for the primary deficit measure, i.e., once the interest payments are excluded. Period and sub-period averages of the actual values of these variables over 1970-2000 are provided in Table 2.

Table 3 presents the results for the simple bivariate specification of (4), i.e., assuming that $x_{i, l}^{*}$ is an empty set. ${ }^{15}$ The first panel uses the nominal deficit measure (including interest payments) and shows that standard errors associated with PMGE are far smaller than those associated with fixed effects and $\mathrm{MG}$ estimators, with t-ratios well above the standard 1 percent or 5 percent significance levels. The Hausman test cannot reject the long-run homogeneity restriction at the usual 5 percent or 10 percent levels, suggesting that the PMGE is more efficient than the MG estimator and should be preferred. The estimated long-run coefficient of 0.35 indicates that a 1 percentage point reduction in the ratio of fiscal deficit to M1 should lead to a long-term reduction in inflation of about a third of a percentage point. Given that the ratio of M1 to GDP typically lies in the 5 to 20 percent range (see Table 2), this implies that a 1 percentage point reduction in the ratio of fiscal deficit to GDP would lead to 2 to 7 percentage point reduction in the inflation rate. The estimated coefficient of 0.44 for the error correction term indicates that about 45 percent of the deviation from the long-run equilibrium following a shock is corrected for within one year.

The second panel of the table uses the more standard specification which scales nominal deficit by GDP. The PMGE estimate of the coefficient on the deficit variable is similar to those of the upper panel; however, since G-T is now scaled by GDP rather than by $\mathrm{M} 1$, the estimated impact of changes in the fiscal balance on inflation is lower. However, the t-ratio on the coefficient on $(G-T) / G D P$ is also much lower indicating that $\beta$ is not so precisely estimated. At the same time, the point estimates using static fixed effects and the MG estimator are implausibly high.

One possible reason for the poor performance of the latter specification is the presence of non-linearities in the fiscal deficit-inflation relationship. Note that in the above specification a 1 percentage point change in $(G-T) / G D P$ leads to the same x percentage point fall in inflation regardless of the level of inflation, which may be unrealistic. A simple way to address this problem is to measure inflation by the approximation $\pi \approx \ln (1+\pi)$, as in Fischer, Sahay, and Végh (2000). In this case, the percentage point response of inflation

that they have tended to move together. Thus, we would not expect our results to change substantially if more comprehensive fiscal balance measures could be used.

${ }^{15}$ In all regressions, the optimal lag structure (p,q) was chosen by the Schwartz Bayesian Criterion (SBC) and constrained to $(p, q) \leq 2$ in order to conserve on degrees of freedom. Limiting the number of lags to at most two is a commonly used procedure for models involving a large number of parameters and estimated with annual data. In more than half of the countries, the SBC indicated that one lag of the dependent variable was enough. 
to percentage point changes in $(G-T) / G D P$ will increase as inflation rises. ${ }^{16}$ At the same time, since the log approximation helps flatten out extreme variations in the inflation rate, this way of measuring inflation plays down the impact of outlier observations, such as during hyperinflations. Panel $\mathrm{c}$ of Table 3 presents the results using this alternative measure of inflation. As expect, estimates using static fixed effects and the MG estimator now look much more reasonable, pointing to a substantially stronger effect of fiscal consolidation on inflation compared with those of panel 3.b. Indeed, the fixed effect estimate of 3 is close to that obtained by Fischer, Sahay, and Végh (2000) which found that a 1 percentage point reduction in the ratio of fiscal deficit to GDP tends to lower inflation by 4.2 percent in high inflation countries. Also as expected, the PMGE estimate is virtually unaffected by the use of the log approximation, reflecting its robustness to outlier observations as discussed earlier.

The bottom panel of Table 3 reports the results using the primary deficit concept and keeping the Fischer, Sahay, and Végh (2000) log approximation measure of inflation. The Hausman test cannot reject the cross-equation homogeneity restriction, and the PMGE coefficient on the deficit variable is strikingly close to the estimates using the nominal deficit concept. The associated t-ratio is also reasonably high, and the error correction coefficient of -0.4 is very similar to that yielded by the total deficit measure. This suggests that the previous results have not been seriously distorted by endogeneity biases arising from feedback effects of current inflation on debt interest payments, at least in the long-term.

In sum, bi-variate panel regressions using the PMGE point to a positive and statistically significant long-run relationship between government deficits and inflation. This inference is robust whether one scales the nominal deficit by GDP or by M1, excludes or includes debt interest payments in the deficit concept, or uses the standard percentage change measure inflation instead of its log approximation. The same conclusion would not follow, however, if one were to focus on fixed effects or MG estimators, both of which yielded disparate point estimates of $\hat{\beta}$ and generally much lower t-ratios across the various specifications.

We test next the robustness of our preferred specification-with the total fiscal deficit being scaled by $\mathrm{M} 1$ - for omitted variable biases. Table 4 reports results for the inclusion of two measures of external inflation - the percent changes in the international (US dollar) oil price, and a measure of global inflation provided in the IMF's International Financial Statistics. ${ }^{17}$ Once again, Hausman tests indicate that the long-run homogeneity restriction

${ }^{16}$ This can be readily seen by substituting $\pi \approx \ln (1+\pi)$ and taking the derivative of $(1)$, which yields: $\frac{\partial \pi}{\partial[(G-T) / G D P]} \approx \beta(1+\pi)$. Thus, for given estimate of $\beta$, the impact of a percentage change in the fiscal deficit/GDP ratio on inflation will be higher as $\pi$ increases.

${ }^{17}$ For discussion of the channels through which these two variables can affect inflation trends in emerging markets, see International Monetary Fund (2001). 
cannot be rejected at a 5 percent level; hence, the PMGE ought to be preferred to fixed effects and MG estimators. The estimated coefficients on oil price changes and world inflation turn out to be associated with very high t-ratios, indicating that those two variables have a statistically significant and positive long-term impact on EM inflation. Consistent with the findings of other studies, the quantitative impact of oil prices on domestic EM inflation is modest (see Loungani and Swagel, 2001), whereas the impact of world inflation-which largely reflect developed country trends-is substantial, indicating that a percentage point increase in world inflation leads a one-third of percentage point increase in emerging market inflation in the long-term. The addition of these two explanatory variables do not change the statistical significance of the inflation-fiscal deficit connection: not only does the fiscal deficit variable continue to be estimated with striking precision, thus yielding a very high t-ratio, but also its coefficient of 0.31 is very similar to that obtained with the bivariate specification (see Table 3). As previously, if only fixed effects or MG estimators had been considered, one would be inclined to (incorrectly) accept the null of no significant relationship between the fiscal deficit and inflation.

The significance of previous results also proved to be robust to the inclusion of two other explanatory variables. One is openness to foreign trade. The hypothesis that inflation tends to be lower in more opened economies is a direct and testable implication of the timeinconsistency theory of monetary policy. ${ }^{18}$ As argued in Romer (1993) and Lane (1995), the benefits of an expansionary monetary policy tend to be smaller in an economy with a larger share of imports in GDP because: (i) the weight of the home goods sector will be smaller implying that the impact of monetary expansion on domestic employment will be reduced; and (ii) the currency depreciation resulting from the monetary expansion will raise domestic inflation by more than in a closed economy. So, a negative cross-sectional relationship between inflation and openness should be expected. Our results, however, lend little support to the view of openness as an independent contributing factor to lower long-run inflation. When openness (measured as in Romer, i.e., the ratio of imports to GDP) is included in the regression alone, it has the expected sign and yields a t-ratio of -3.1 . However, when oil prices and world inflation are included, the openness variable becomes statistically insignificant (Table 5). And when the fiscal variable is included, the openness variable changes sign and turns out to be positively related to inflation, inconsistent with the RomerLane story. Such a dependence of the openness coefficient on the inclusion of the fiscal deficit variable in the equation seems to suggest that, if greater trade openness contributes to

\footnotetext{
${ }^{18}$ The other testable hypothesis derived from the time inconsistency theory and which has been examined in previous studies is that inflation tends to be lower in countries with more independent central banks (Cuckierman et al., 1992; de Haan and Kooi, 2000). However, the lack of time series on central bank independence measures for our sample of countries during the 1970-2000 period prevented us from testing its significance.
} 
lower inflation, it may be via the fiscal channel-for instance, by imposing greater discipline on the behavior of the fiscal authorities. ${ }^{19}$

The other potentially important determinant of inflation is the exchange rate regime. It can be argued, for instance, that fixed exchange rate regimes, by tying domestic inflation to that of a lower inflation country and being more conducive to fiscal and monetary discipline, tend to lower inflation rates (Gosh et. al., 1995). We have tried to capture differences in exchange rate regimes by including in the regressions a dummy variable defined as one for pegged exchange rate regimes and zero otherwise, based on the IMF's de jure classification of exchange rate arrangements. However, no evidence was found of a statistically significant relationship between pegged exchange rates and inflation. As shown in Table 6, even though the respective short-run coefficient yields the expected negative sign, the associated t-ratio is well below usual levels of statistical significance - a result that holds regardless of whether one uses the PMGE, the MG or static fixed effects estimators. Setting aside the well-known problems with de facto vs. de jure classification methods, a rationale for the results of Table 6 is that the direct impact of fixed exchange rates on inflation is mainly through the fiscal channel, consistent with the view that pegged exchange rate regimes are more conducive to fiscal discipline than flexible exchange rates. ${ }^{20}$ This interpretation is supported by the estimates, which show a significant drop on the coefficient of the deficit/M1 variable once the exchange rate dummy is added to the model.

Finally, we test the robustness of the previous results for the presence of outliers. While it has been noted that the PMGE is better suited to handle extreme observations than static or dynamic fixed effects estimators, one should still examine whether coefficients change radically once countries that experienced very high or hyper-inflations are excluded from the sample as, for instance, Fischer, Sahay, and Végh (2000) have found. The three countries in our sample with very high historical inflation rates and which also underwert hyperinflations are Argentina, Brazil and Peru. Table 7 reports the results once they are excluded from the sample. Not only does the coefficient on the fiscal deficit remains the same and continues to yield a very high t-ratio, but also the significance of the other two explanatory variables - oil price changes and world inflation-remain unaffected. Since the exclusion of these variables also serves as an additional test for potential endogeneity biases as discussed above, the results of Table 7 provide further support for the robustness of the estimates reported in Tables 3 and 4.

${ }^{19}$ A recent study has found a positive correlation between openness and government size (Rodrik, 1998). It has been suggested that this positive correlation may reflect the use of government spending as an external risk-reducing device.

${ }^{20}$ This belief has been qualified, however, by Fatás and Rose (2001) and more radically questioned by Tornell and Velasco (2000). The results of Table 6 have also to be cautioned by the difficulties in distinguishing between the regimes on the basis of a de facto v. de jure classification system. See Levy-Yeyati and Sturzenegger (2000). 
To sum up, the fiscal deficit-inflation relationship appears to be positive, relatively strong, and statistically significant in EMs. The estimates presented proved to be remarkably robust across a wide range of specifications. With the ratio of M1 to GDP being typically in the 5 to 20 percent range (see Table 2), the estimated coefficient of $1 / 3$ on (G-T)/M1 implies that a 1 percentage point reduction in the ratio of fiscal deficit to GDP typically leads to a $1 \frac{1}{2}$ to 6 percentage point reduction in the equilibrium inflation rate. As discussed above, those figures are roughly consistent with the semi-elasticity figure reported by Fischer, Sahay and Végh (2000) for high inflation countries. However, in contrast with those authors as well as with the bulk of the literature, we find that those estimates are statistically significant for a wider range of inflation rates.

This leads us to the question of why previous cross-country econometric studies have not found such a strong association between fiscal deficits and inflation. One main reason appears to be the use of econometric techniques unsuitable for modeling inflation dynamics or handling highly heterogeneous panels. Indeed, we have shown that the use of standard fixed effects estimates generally yield low t-ratios and unstable coefficients across the different specifications considered; the same applies to the MG estimator, reflecting its failure to make use of the information contained in the cross-equation restrictions. The other possible reason for our distinctive results is the choice of countries. To the extent that fiscal dominance tends to be more prevalent among EMs and access to external financing is more restricted than for advanced countries, the higher the likelihood of one's finding a tighter relationship between fiscal deficits and inflation in panels comprising only EMs. Thus, one interesting extension of this paper would be to apply the same econometric framework to a broader sample of countries comprising also advanced economies, and examine the generality of our results.

\section{Conclusions}

Economic theory postulates a clear causal connection between fiscal deficits and inflation in the long-run. However, this relationship is not easily detectable in the data. One reason is the complex short-run dynamics of high inflation processes: as stressed by Calvo and Végh (1999) in their recent survey of the literature, once inflation rises to double- or triple-digit levels, strong feedback effects between the main macro variables make it very hard to identify the ultimate culprit(s). The other reason is that the relationship between fiscal deficits and inflation tends to be less obvious in countries with institutional arrangements that curb fiscal dominance, and that have wide access to external financing and broader seignorage tax bases. To the extent such cross-country differences can be considerable, they make it harder to uncover a strong and stable relationship between the two variables in panels with highly heterogeneous country groups. These problems have no doubt plagued previous studies, which had little success in establishing a statistically significant connection between inflation and fiscal deficits across a broad range of countries and inflation rates. 
This paper has sought to address these empirical problems by: (i) using a theoretically grounded model that scales the fiscal deficits by narrow money so as to control for differences in the inflation tax base; (ii) employing an econometric specification that allows for rich dynamics, does not constrain the short-run parameters of the model to be the same across countries, and explicitly distinguishes between short- and long-run relationships in the panel; and (iii) focusing on EMs. The main findings can be summarized as follows. First, fiscal deficits bear a strongly positive and statistically significant long-run relationship with inflation. The statistical significance of this relationship appears to be robust to variable addition tests, the use of alternative fiscal deficit measures, and the exclusion of hyperinflation episodes from the sample. Second, the hypothesis of cross-country homogeneity of this long-run relationship cannot be rejected; this is so despite wide differences in the estimated short-run coefficients across countries. Third, only world inflation and oil price changes proved to be significant independent determinants of inflation besides fiscal deficits. Two other variables much heralded in the inflation literatureopenness to foreign trade and the distinction between fixed vs. flexible exchange rate regimes - did not yield results consistent with the theoretical priors. In all specifications considered, the statistical significance of those two variables could only be maintained as long as the fiscal variable was omitted. This possibly suggests that trade openness and fixed exchange rates contribute to lower inflation mainly through the fiscal channel.

As always with empirical work, care must be taken not to infer too much from the data. This is especially advisable when dealing with a phenomenon as complex as inflation, in which several variables interact dynamically and non-economic factors may play a role. Bearing in mind this caveat, some clear policy implications follow from our results. First, fiscal consolidation appears to be a key requirement for long-lasting price stability. Second, the external environment - specifically through low oil prices and monetary stability in the developed world - also plays a crucial role. Putting the two together, it appears that the dramatic decline in EM inflation over the past ten years or so can be largely explained by domestic fiscal consolidation aided by falling world inflation and-to a lesser extent-lower oil prices.

Third, a given deficit will tend to produce more inflation in countries with lower levels of monetization or narrower inflation tax bases. On the one hand, this corroborates the findings of previous authors indicating that the relationship between inflation and the ratio of fiscal deficit to GDP is non-linear: the higher the inflation rate and the lower the inflation tax base, the greater the inflationary impact of the deficit. On the other hand, the dependence of inflation on the size of the inflation tax base also implies that other factors that affect private sector holdings of domestic money will also impact on inflation. One such a factor that has especial relevance to some EMs is currency substitution and the dollarization of financial intermediation. To the extent that the ratio of domestic M1 to GDP in a semi-dollarized country is much lower than that in a non-dollarized economy, the same fiscal deficit (measured as a ratio to GDP) will tend to produce a higher inflation in the dollarized economy, simply because of differences in the size of the respective inflation tax bases. This corroborates the conventional wisdom that stricter fiscal discipline is required under partial dollarization, if exchange rate stability and low inflation are to be preserved. 


\section{Figure 1. Inflation over time}

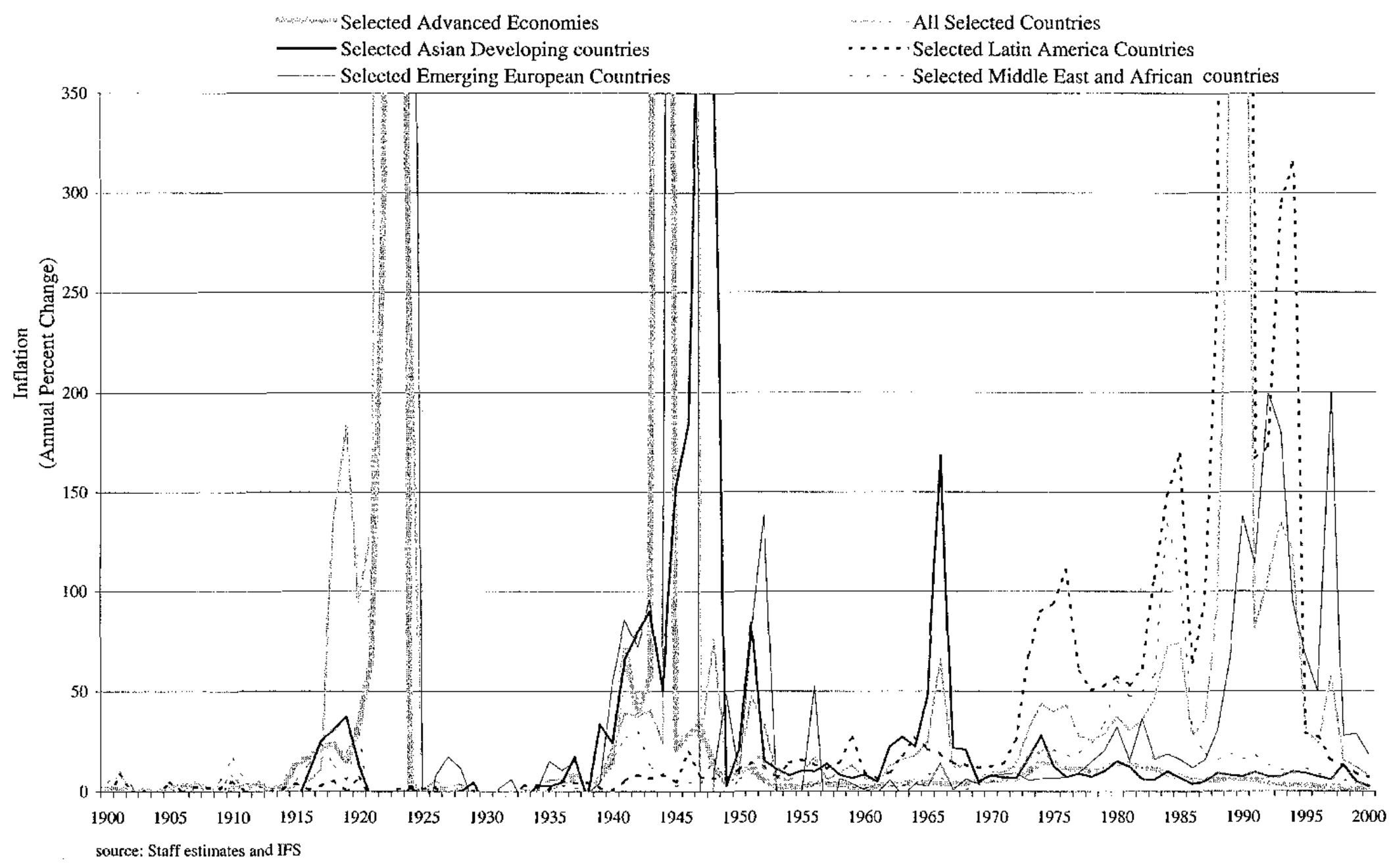


Table 1. Inflation in Developed Countries and Emerging Markets 1/ (percent a year)

\begin{tabular}{|c|c|c|c|c|c|c|c|c|c|}
\hline & $1900-13$ & $1930-39$ & $1950-60$ & $1961-70$ & $1971-80$ & $1981-90$ & 1991-95 & $1996-2000$ & 2000 \\
\hline Advanced Countries & 1.5 & 0.3 & 4.3 & 4.0 & 10.8 & 8.1 & 3.9 & 2.0 & 2.5 \\
\hline All Selected Emerging Markets & 1.1 & 2.0 & 14.2 & 17.5 & 27.8 & 119.8 & 80.4 & 13.0 & 7.2 \\
\hline $\begin{array}{l}\text { Selected Emerging Markets exc. } \\
\text { Indonesia, Venezuela, Turkey, and } \\
\text { Zimbabwe }\end{array}$ & 1.1 & 3.2 & 14.8 & 18.5 & 39.1 & 136.5 & 82.4 & 8.1 & 4.3 \\
\hline
\end{tabular}


Table 2. Emerging Market Countries: Selected Variables

(Percent of GDP unless otherwise noted)

\begin{tabular}{|c|c|c|c|c|c|c|c|c|}
\hline Pcriods & $\begin{array}{l}\text { Inflation } \\
(\mathrm{CPI})^{1}\end{array}$ & $\begin{array}{c}\text { Total Fiscal } \\
\text { Balance } / \\
\text { GDP }\end{array}$ & $\begin{array}{c}\text { Primary Balance / } \\
\text { GDP }\end{array}$ & $\begin{array}{c}\text { Government } \\
\text { Expenditures / } \\
\text { GDP }\end{array}$ & Oil Prices & $1 \quad$ Global Prices & I Imports / GDP & $\mathrm{M} 1 / \mathrm{GDP}$ \\
\hline \multicolumn{9}{|c|}{ All Emerging Markets } \\
\hline $1971-80$ & $2 \mathrm{I} .53$ & -4.72 & -3.49 & 22.39 & 43.93 & 10.37 & 23.39 & 15.52 \\
\hline $1981-85$ & 43.53 & -5.38 & -2.11 & 30.94 & -6.07 & 15.45 & 25.05 & 15.86 \\
\hline $1986-90$ & 168.33 & -3.87 & 0.27 & 28.78 & 2.19 & 16.61 & 24.03 & 14.19 \\
\hline $1991-95$ & 89.66 & -2.73 & 1.60 & 27.71 & -5.28 & 18.40 & 29.49 & 14.51 \\
\hline $1996-2000$ & 24.43 & -2.94 & 1.66 & 28.08 & 15.06 & 5.92 & 32.92 & 15.97 \\
\hline \multicolumn{9}{|l|}{ Latin America } \\
\hline $1971-80$ & 56.71 & -2.34 & -1.94 & 15.50 & 43.93 & 10.37 & 15.65 & 11.17 \\
\hline $1981-85$ & 100.19 & -4.21 & -1.41 & 21.53 & -5.66 & 15.49 & 15.02 & 8.91 \\
\hline $1986-90$ & 606.23 & -4.39 & 0.37 & 20.62 & 2.19 & 16.61 & 15.80 & 7.50 \\
\hline $1991-95$ & 179.23 & -0.91 & 1.81 & 19.40 & -5.28 & 18.40 & 18.11 & 6.77 \\
\hline $1996-2000$ & 14.18 & -1.96 & 0.64 & 20.01 & 15.06 & 5.92 & 19.97 & 7.75 \\
\hline \multicolumn{9}{|l|}{ Asia } \\
\hline $1971-80$ & 10.17 & -3.47 & -2.33 & 16.66 & 43.93 & 10.37 & 19.86 & 13.40 \\
\hline $1981-85$ & 8.34 & -5.00 & -2.36 & 20.09 & -5.66 & 15.49 & 25.35 & 14.51 \\
\hline $1986-90$ & 6.51 & -3.19 & 0.45 & 19.80 & 2.19 & 16.61 & 26.40 & 15.78 \\
\hline $1991-95$ & 8.60 & -1.23 & 1.85 & 18.68 & -5.28 & 18.40 & 33.54 & 17.27 \\
\hline $1996-2000$ & 6.83 & -2.81 & 0.18 & 18.87 & 15.06 & 5.92 & 38.28 & 19.11 \\
\hline \multicolumn{9}{|l|}{ Europe ${ }^{2}$} \\
\hline $1971-80$ & 6.10 & -2.53 & -2.02 & 18.63 & 43.93 & 10.37 & 24.42 & 16.21 \\
\hline $1981-85$ & 14.22 & -2.35 & -1.24 & 38.01 & -5.66 & 15.49 & 24.31 & 18.54 \\
\hline $1986-90$ & 44.93 & -2.47 & -0.15 & 39.06 & 2.19 & 16.61 & 24.24 & 14.44 \\
\hline $1991-95$ & 156.63 & -4.49 & 0.81 & 37.91 & -5.28 & 18.40 & 34.40 & 13.74 \\
\hline $1996-2000$ & 65.29 & $-3,43$ & 2.51 & 36.06 & 15.06 & 5.92 & 41.09 & 13.27 \\
\hline \multicolumn{9}{|c|}{ Africa and the Middle East } \\
\hline $1971-80$ & 13.12 & -10.55 & -7.68 & 38.77 & 43.93 & 10.37 & 33.64 & 21.29 \\
\hline $1981-85$ & 51.38 & -9.98 & -3.44 & 44.15 & -7.30 & 15.35 & 35.55 & 21.46 \\
\hline $1986-90$ & 15.65 & -5.41 & 0.40 & 35.65 & 2.19 & 16.61 & 29.68 & 19.04 \\
\hline $1991-95$ & 14.19 & -4.28 & 1.93 & 34.86 & -5.28 & 18.40 & 31.92 & 20.25 \\
\hline $1996-2000$ & 11.41 & -3.55 & 3.32 & 37.37 & 15.06 & 5.92 & 32.36 & 23.74 \\
\hline
\end{tabular}

Sources: International Financial Statistics; and IMF staff estimates.

1/ Average annual percent change.

2/ Includes Bulgaria, Czech Republic, Hungary, Poland, Russia, and Turkey. 
Table 3. Estimates of Inflation on Government Deficit

a) Total Deficit/M1

\begin{tabular}{lcccc}
\hline & $\begin{array}{c}\text { Pooled Mean } \\
\text { Estimator }\end{array}$ & $\begin{array}{c}\text { Mean Group } \\
\text { Estimator }\end{array}$ & $\begin{array}{c}\text { Static Fixed } \\
\text { Effects Estimate }\end{array}$ & $\begin{array}{c}\text { Individual } \\
\text { Hausman Test }\end{array}$ \\
\hline $\begin{array}{l}\text { Government deficit/M1 } \\
\text { t-ratio }\end{array}$ & $\mathbf{0 . 3 5}$ & 2.13 & 1.35 & 2.51 \\
$\quad$ p-value & 18.94 & 1.90 & 1.69 & 0.11 \\
& & & & \\
$\begin{array}{l}\text { Error correction coefficient } \\
\text { t-ratio }\end{array}$ & -0.44 & -0.56 & & \\
\hline
\end{tabular}

b) Total Deficit/GDP

\begin{tabular}{lcccc}
\hline & $\begin{array}{c}\text { Pooled Mean } \\
\text { Estimator }\end{array}$ & $\begin{array}{c}\text { Mean Group } \\
\text { Estimator }\end{array}$ & $\begin{array}{c}\text { Static Fixed } \\
\text { Effects Estimate }\end{array}$ & $\begin{array}{c}\text { Individual } \\
\text { Hausman Test }\end{array}$ \\
\hline $\begin{array}{l}\text { Government deficit/GDP } \\
\text { t-ratio } \\
\text { p-value }\end{array}$ & $\mathbf{0 . 2 7}$ & 38.70 & 14.22 & 3.16 \\
$\quad 2.52$ & 1.79 & 2.01 & 0.08 \\
$\begin{array}{l}\text { Error correction coefficient } \\
\text { t-ratio }\end{array}$ & -0.44 & -0.49 & & \\
\hline
\end{tabular}

c) Total Deficit/GDP, inflation $=\ln (1+\pi)$

\begin{tabular}{lcccc}
\hline & $\begin{array}{c}\text { Pooled Mean } \\
\text { Estimator }\end{array}$ & $\begin{array}{c}\text { Mean Group } \\
\text { Estimator }\end{array}$ & $\begin{array}{c}\text { Static Fixed } \\
\text { Effects Estimate }\end{array}$ & $\begin{array}{c}\text { Individual } \\
\text { Hausman Test }\end{array}$ \\
\hline $\begin{array}{l}\text { Government deficit/GDP } \\
\text { t-ratio }\end{array}$ & $\mathbf{0 . 3 3}$ & 6.50 & 2.98 & 4.13 \\
p-value & 2.74 & 2.12 & 3.13 & 0.04 \\
$\begin{array}{l}\text { Error correction coefficient } \\
\text { t-ratio }\end{array}$ & -0.41 & & & \\
\hline
\end{tabular}

d) Primary Deficit/GDP, inflation $=\ln (1+\pi)$

\begin{tabular}{lcccc}
\hline & $\begin{array}{c}\text { Pooled Mean } \\
\text { Estimator }\end{array}$ & $\begin{array}{c}\text { Mean Group } \\
\text { Estimator }\end{array}$ & $\begin{array}{c}\text { Static Fixed } \\
\text { Effects Estimate }\end{array}$ & $\begin{array}{c}\text { Individual } \\
\text { Hausman Test }\end{array}$ \\
\hline $\begin{array}{l}\text { Primary deficit/GDP } \\
\text { t-ratio }\end{array}$ & $\mathbf{0 . 3 0}$ & 0.89 & 61.2 & 1.19 \\
p-value & 4.27 & 4.27 & 1.09 & 0.28 \\
$\begin{array}{l}\text { Error correction coefficient } \\
\text { t-ratio }\end{array}$ & -0.42 & -0.42 & & \\
\hline
\end{tabular}


Table 4. Estimates of Inflation on Government Deficit, Oil Prices, and World Inflation.

Total Deficit/M1, Oil Prices, and World Inflation

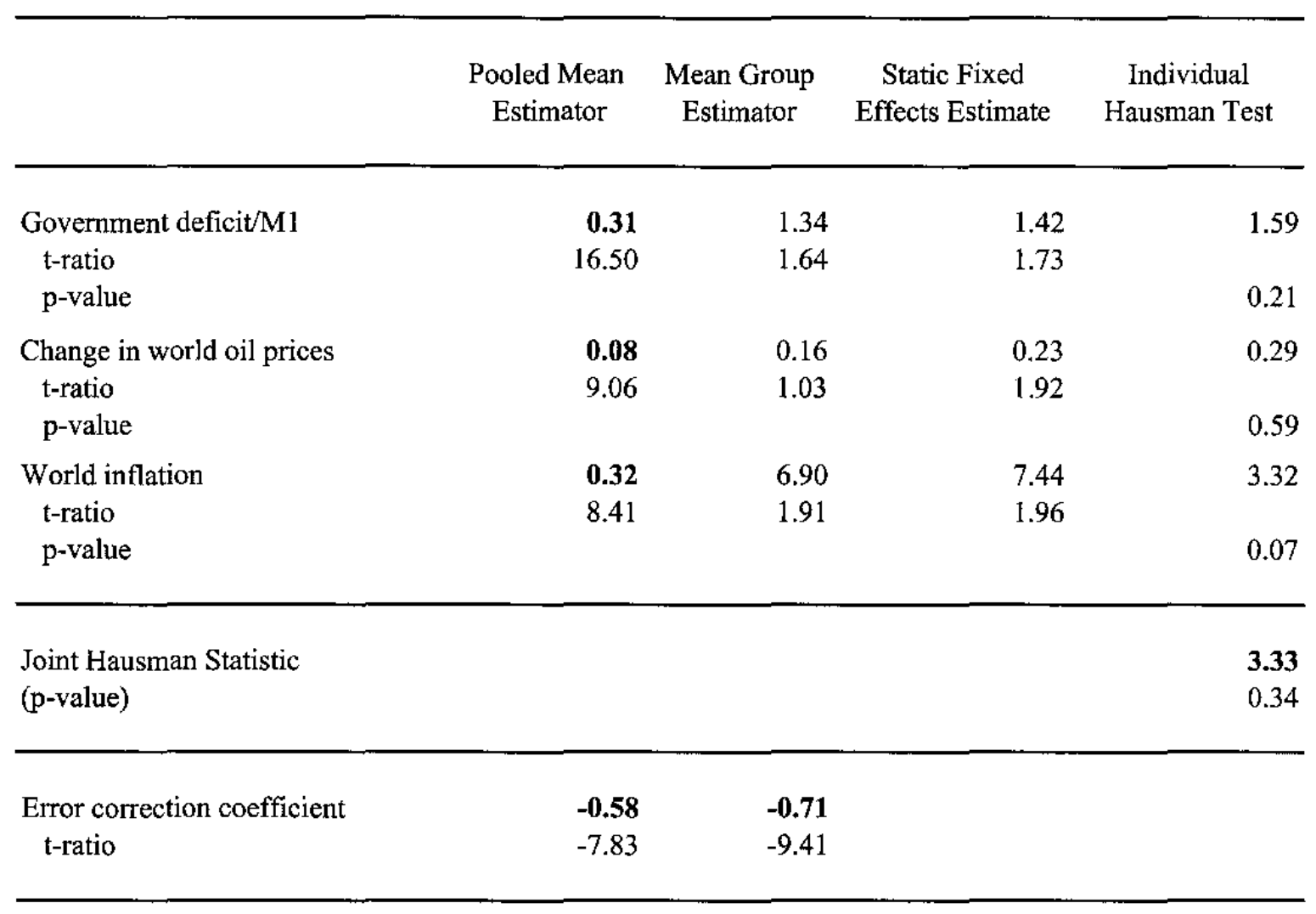


Table 5. Estimates of Inflation on Openness, Oil Prices, World Inflation, and Government Deficits.

a. Openness, Oil Prices, and World Inflation

\begin{tabular}{|c|c|c|c|c|}
\hline & $\begin{array}{l}\text { Pooled Mean } \\
\text { Estimator }\end{array}$ & $\begin{array}{l}\text { Mean Group } \\
\text { Estimator }\end{array}$ & $\begin{array}{c}\text { Static Fixed } \\
\text { Effects Estimate }\end{array}$ & $\begin{array}{c}\text { Individual } \\
\text { Hausman Test }\end{array}$ \\
\hline Openness & -0.03 & -5.31 & -1.90 & 1.02 \\
\hline t-ratio & -1.01 & -1.02 & -1.37 & \\
\hline p-value & & & & 0.31 \\
\hline Change in world oil prices & 0.05 & -0.09 & 0.10 & 0.96 \\
\hline t-ratio & 6.82 & -0.62 & 1.27 & \\
\hline $\mathrm{p}$-value & & & & 0.33 \\
\hline World inflation & 0.09 & 6.59 & 6.45 & 2.93 \\
\hline t-ratio & 2.04 & 1.74 & 1.76 & \\
\hline p-value & & & & 0.09 \\
\hline Joint Hausman Statistic & & & & 3.29 \\
\hline (p-value) & & & & 0.35 \\
\hline Error correction coefficient & -0.50 & -0.58 & & \\
\hline t-ratio & -8.28 & -8.18 & & \\
\hline
\end{tabular}

b. Openness, Oil Prices, World Inflation, and Total Government Deficit

\begin{tabular}{|c|c|c|c|c|}
\hline & $\begin{array}{l}\text { Pooled Mean } \\
\text { Estimator }\end{array}$ & $\begin{array}{l}\text { Mean Group } \\
\text { Estimator }\end{array}$ & $\begin{array}{c}\text { Static Fixed } \\
\text { Effects Estimate }\end{array}$ & $\begin{array}{c}\text { Individual } \\
\text { Hausman Test }\end{array}$ \\
\hline Government Deficit/Ml & 0.34 & 1.82 & 1.44 & 2.04 \\
\hline $\begin{array}{l}\text { t-ratio } \\
\text { p-value }\end{array}$ & 19.18 & 1.75 & 1.76 & 0.15 \\
\hline Change in world oil prices & 0.08 & 0.18 & 0.22 & 0.21 \\
\hline t-ratio & 9.30 & 0.82 & 1.93 & \\
\hline p-value & & & & 0.65 \\
\hline World inflation & 0.33 & 4.76 & 7.32 & 2.17 \\
\hline t-ratio & 7.97 & 1.58 & 1.96 & \\
\hline p-value & & & & 0.14 \\
\hline Openness & 0.35 & 0.15 & -2.50 & 0.00 \\
\hline t-ratio & 4.48 & 0.02 & -1.27 & \\
\hline p-value & & & & 0.98 \\
\hline Joint Hausman Statistic & & & & 3.27 \\
\hline (p-value) & & & & 0.51 \\
\hline Error correction coefficient & -0.62 & -0.76 & & \\
\hline t-ratio & -8.16 & -8.64 & & \\
\hline
\end{tabular}


Table 6. Estimates of Inflation on Government Deficit, Oil Prices, World Inflation, and Fixed Exchange Rate Dummy.

\begin{tabular}{|c|c|c|c|c|}
\hline & $\begin{array}{l}\text { Pooled Mean } \\
\text { Estimator }\end{array}$ & $\begin{array}{l}\text { Mean Group } \\
\text { Estimator }\end{array}$ & $\begin{array}{l}\text { Static Fixed } \\
\text { Effects Estimate }\end{array}$ & $\begin{array}{c}\text { Individual } \\
\text { Hausman Test }\end{array}$ \\
\hline \multirow{3}{*}{$\begin{array}{l}\text { Government deficit/M1 } \\
\text { t-ratio } \\
\text { p-value }\end{array}$} & 0.09 & 1.26 & 1.45 & 2.11 \\
\hline & 4.63 & 1.56 & 1.78 & \\
\hline & & & & 0.15 \\
\hline \multirow{3}{*}{$\begin{array}{l}\text { Change in world oil prices } \\
\text { t-ratio } \\
\text { p-value }\end{array}$} & 0.06 & 0.06 & 0.23 & 0.00 \\
\hline & 9.29 & 0.52 & 1.83 & \\
\hline & & & & 0.98 \\
\hline \multirow{3}{*}{$\begin{array}{l}\text { World inflation } \\
\text { t-ratio } \\
\text { p-value }\end{array}$} & 0.23 & 7.42 & 7.74 & 3.27 \\
\hline & 8.00 & 1.96 & 2.00 & \\
\hline & & & & 0.07 \\
\hline \multirow{2}{*}{$\begin{array}{l}\text { Joint Hausman Statistic } \\
\text { (p-value) }\end{array}$} & & & & 3.70 \\
\hline & & & & 0.30 \\
\hline \multirow{2}{*}{$\begin{array}{l}\text { Error correction coefficient } \\
\text { t-ratio }\end{array}$} & -0.66 & -0.74 & & \\
\hline & -10.13 & -9.76 & & \\
\hline \multirow{2}{*}{$\begin{array}{l}\text { Fixed Exchange Rate Dummy } \\
\text { t-ratio }\end{array}$} & -29.37 & -55.05 & -45.62 & \\
\hline & -1.16 & -0.83 & -1.20 & \\
\hline
\end{tabular}


Table 7. Estimates of Inflation on Government Deficit, Oil Inflation, excluding Countries that experienced Hyperinflation 1/

\begin{tabular}{lcccc}
\hline & $\begin{array}{c}\text { Pooled Mean } \\
\text { Estimator }\end{array}$ & $\begin{array}{c}\text { Mean Group } \\
\text { Estimator }\end{array}$ & $\begin{array}{c}\text { Static Fixed } \\
\text { Effects Estimate }\end{array}$ & $\begin{array}{c}\text { Individual } \\
\text { Hausman Test }\end{array}$ \\
\hline $\begin{array}{l}\text { Government deficit/M1 } \\
\text { t-ratio } \\
\text { p-value }\end{array}$ & $\mathbf{0 . 3 1}$ & 0.31 & 0.28 & 0.00 \\
$\begin{array}{l}\text { Change in world oil prices } \\
\text { t-ratio }\end{array}$ & 16.42 & 1.06 & 9.72 & 1.00 \\
p-ratio & $\mathbf{0 . 0 8}$ & 0.07 & 0.09 & 0.00 \\
$\begin{array}{l}\text { World inflation } \\
\text { t-ratio } \\
\text { p-value }\end{array}$ & 9.07 & 0.75 & 1.34 & 0.96 \\
\hline $\begin{array}{l}\text { Joint Hausman Statistic } \\
\text { (p-value) }\end{array}$ & $\mathbf{0 . 3 2}$ & 0.46 & 0.37 & 0.18 \\
\hline & 8.40 & 1.44 & 3.15 & 0.67 \\
Error correction coefficient & & & & 0.69 \\
t-ratio & -0.56 & & & 0.88 \\
\hline
\end{tabular}

1/ Namely: Argentina, Brazil, and Peru. 


\section{Appendix I}

We derive the specification of the fiscal deficit-inflation relationship from a very simple model - a small open economy version of the class of general equilibrium models surveyed by Ljungqvist and Sargent (2000). In this framework, money plays a role in the determination of macroeconomic equilibria through a reduction in transactions costs ("shopping time"). Our stylized economy has an one-good endowment, flexible exchange rate and prices, and faces an exogenous world interest rate. It is inhabited by infinitely living households and a government whose behavior are described as follows.

\section{Households}

The representative household is endowed, in each period of time, with a constant quantity of the only good $y_{t}$ (where $y_{t}>0$ ), and has the following lifetime utility function defined over consumption $\left(\mathrm{c}_{\mathrm{t}}\right)$ and leisure $\left(l_{\mathrm{t}}\right)$ :

$$
\sum_{i=0}^{\infty} \beta^{t} u\left(c_{t}, t_{t}\right)
$$

where $\mathrm{o}$ is the subjective discount factor $(0<\beta<1)$, and $\mathrm{u}(\ldots)$ is assumed to be strictly increasing in $c_{t}$ and $t_{t}$ and strictly concave. The household is subject to a sequence of budget constraints given by:

$$
c_{t}+\frac{b_{t+1}^{p}}{R_{t}^{*}}+\frac{m_{t+1}}{p_{t}}=y_{t}-\tau_{t}+b_{t}^{p}+\frac{m_{t}}{p_{t}}
$$

where $b_{t}^{p}$ is the real value of the household holdings of one-period financial assets that mature at the beginning of period $t$, these assets are denominated in period $t$ consumption units; $\mathrm{m}_{t+1}$ are the household's holdings of money balances; $\tau_{t}$ is a tax at period $\mathrm{t} ; \mathrm{p}_{\mathrm{t}}$ is the price level; and $R_{t}^{*}$ is the international gross rate of return on one-period financial assets. The initial stocks of $b_{0}^{p}$ and $\mathrm{m}_{0}$ are given.

In order to consume, the household has to spent time shopping. In each period, the household has one unit of time, which can be allocated to leisure $\left(l_{t}\right)$ or shopping $\left(s_{t}\right)$ :

$$
l_{t}+s_{t}=1
$$

Shopping time is directly related to the level of consumption and inversely related to the amount of real balances the household has $\left(\mathrm{m}_{\mathrm{t}+1} / \mathrm{p}_{\mathrm{t}}\right)$ : 


$$
s_{t}=S\left(c_{t}, \frac{m_{t+1}}{p_{t}}\right)
$$

where $\mathrm{S}, \mathrm{S}_{\mathrm{c}}, \mathrm{S}_{\mathrm{cc}}, \mathrm{S}_{\mathrm{m} / \mathrm{p}, \mathrm{m} / \mathrm{p}}>0$ and $\mathrm{S}_{\mathrm{m} / \mathrm{p}}$ and $\mathrm{S}_{\mathrm{c}, \mathrm{m} / \mathrm{p}}<0$.

The first order conditions with respect to $c_{t}, t_{t}, b_{t+1}$, and $m_{t+1}$ are:

$$
\begin{gathered}
u_{c}\left(c_{t}, l_{t}\right)-\lambda_{t}-\varphi_{t} S_{c}\left(c_{t}, \frac{m_{t+1}}{p_{t}}\right)=0 \\
u_{t}\left(c_{t}, l_{t}\right)-\varphi_{t}=0 \\
-\frac{\lambda_{t}}{R_{t}^{*}}+\beta \lambda_{t+1}=0 \\
-\frac{\lambda_{t}}{p_{t}}-\frac{\varphi_{t}}{p_{t}} S_{m / p}\left(c_{t}, \frac{m_{t+1}}{p_{t}}\right)+\beta \frac{\lambda_{t+1}}{p_{t+1}}=0
\end{gathered}
$$

From equations (A.5) to (A.8), one obtains the money demand function: ${ }^{21}$

$$
\frac{m_{t+1}}{p_{t}}=M^{d}\left(c_{t}, \frac{R_{m t}}{R_{t}^{*}}\right)
$$

where $\mathrm{R}_{\mathrm{mt}}=p_{t} / p_{t+1}$ and $\mathrm{M}^{\mathrm{d}}$ is increasing in both $\mathrm{c}_{\mathrm{t}}$ and $\frac{R_{m t}}{R_{t}^{*}}$.

\section{Government}

The government budget constraint is given by:

$$
\frac{b_{t+1}^{g}}{R_{t}^{*}}=\tau_{t}+b_{t}^{g}-g_{t}+\frac{M_{t+1}-M_{t}}{p_{t}}
$$

where $b_{t}^{g}$ is the real value of the government's net financial asset holdings, denominated in consumption units of period $t ; M_{t}$ is currency issued by the government in early $t$. Note that if $b_{t}^{g}<0$, the government is a net borrower in period t. Finally, $b_{0}^{g}$ and $\mathrm{M}_{0}$ are given.

${ }^{21}$ Indeed one gets, $\left(1-\frac{R_{m t}}{R_{t}^{*}}\right)\left[\frac{u_{c}\left(c_{t}, 1-S\left(c_{t}, \frac{m_{t+1}}{p_{t}}\right)\right)}{u_{t}\left(c_{t}, 1-S\left(c_{t}, \frac{m_{t+1}}{p_{t}}\right)\right)}-S_{c}\left(c_{t}, \frac{m_{t+1}}{p_{t}}\right)\right]+S_{m / p}\left(c_{t}, \frac{m_{t+1}}{p_{t}}\right)=0$. 


\section{International arbitrage conditions}

In the absence of trade restrictions and taxes, purchasing power parity (PPP) holds:

$$
p_{t}=e_{t} p_{t}^{*}
$$

where $e_{t}$ is the nominal exchange rate (domestic currency price of one unit of foreign currency) and $p_{i}^{*}$ is the foreign price level. Similarly, in the absence of capital account restrictions and taxes, the uncovered interest rate parity condition will hold:

$$
\left(1+i_{t+1}\right)=\left(1+i_{t+1}^{*}\right) \frac{e_{t+1}}{e_{t}}
$$

where $1+i_{t+1}$ and $1+i^{*}{ }_{t+1}$ are the domestic and foreign gross nominal interest rates. Note that

$$
1+i_{t+1}=\frac{R_{t}}{R_{m t}}
$$

and

$$
1+i_{i+1}^{*}=\frac{R_{t}^{*}}{R_{m t}^{*}}
$$

From (A.11) and (A.12) it follows that:

$$
R_{t}=R_{t}^{*}
$$

The economy wide budget constraint

Assuming $m_{t}=M_{t}$, for all t, and substituting (A.10) into (A.2), we obtain

$$
\frac{b_{t+1}}{R_{t}^{*}}=y_{t}-c_{t}-g_{t}+b_{t}
$$

where $b_{t+1}=b_{t+1}^{p}+b_{t+1}^{g}$, is the net foreign asset holdings of the economy as a whole and $\mathrm{b}_{0}$ is given, so that the current account is defined as $b_{i+1}-b_{t}$.

\section{Stationary Equilibrium}

Assume that

$$
g_{t}=g, \forall t \geq 0, \quad \tau_{t}=\tau, \forall t \geq 1, \quad b_{t}^{g}=b^{g}, \forall t \geq 1
$$


and note that the economy at time 0 may not be in stationary equilibrium. In stationary equilibrium,

$$
\begin{aligned}
& R_{t}=R_{t}^{*}=R, \forall t \geq 0 \\
& \frac{p_{t}}{p_{t+1}}=R_{m}, \forall t \geq 0 \\
& \frac{e_{t}}{e_{t+1}}=\frac{R_{m}}{R_{m}^{*}}, \forall t \geq 0 \\
& c_{t}=c, \forall t \geq 0 \\
& s_{t}=s, \forall t \geq 0
\end{aligned}
$$

Using (A.17) into (A.5)-(A.8) yields:

$$
\begin{aligned}
& R=R^{*}=\beta^{-1} \\
& \frac{M}{p}=M^{d}\left(c, \frac{R_{m}}{R}\right)=\psi\left(R_{m}\right)
\end{aligned}
$$

Substituting (A.17)-(A.18) into (A.10) yields:

$$
g-\tau+b^{g} \frac{(R-1)}{R}=\psi\left(R_{m}\right)\left(1-R_{m}\right)
$$

where the term in the right hand side is seignorage. Noting that the inflation rate $\pi$ is equal to $1-R_{m}$, we can re-write the expression above as:

$$
\pi=\frac{p\left[g-\tau+b^{g} \frac{(R-1)}{R}\right]}{M}
$$

which is the long-term relationship we shall examine empirically. It states that the rate of inflation is directly proportional to the size of the general government deficit (including transfers and interest payments) scaled by narrow money; or equivalently, that inflation is directly proportional to the product of the ratio of fiscal deficit to GDP by the inverse of the ratio of narrow money to GDP. 


\section{REFERENCES}

Alesina, Alberto and Drazen, Allan, 1991, "Why Are Stabilizations Delayed?," American Economic Review, Vol. 81, pp.1170-1188

Atiyas, Izak, Bal Gunduz, Yasemin, Emil, Ferhat, Erdem, Can, and Ozgun, Didem, 1999, "Fiscal Adjustment in Turkey: The Role of Quasi-Fiscal Activities and Institutional Reform," Mimeo.

Banerjee, Anindya, Dolado, Juan, Galbraith, J.W., and Hendry, David F., 1993, Cointegration, Error Correction and the Econometric Analysis of Non-Stationary Data, Oxford: Oxford University Press.

Blanchard, Olivier and Fischer, Stanley, 1989, Lectures on Macroeconomics, Cambridge, Massachusetts: The MIT Press.

Cagan, Philip, 1956, The Monetary Dynamics of Hyperinflation, in Milton Friedman, ed., Studies in the Quantity Theory of Money. Chicago: The University of Chicago Press.

Campillo, Martha and Miron, Jeffrey, 1997, "Why Does Inflation Differ Across Countries?," In Christina Romer and David Romer, eds., Reducing Inflation: Motivation and Strategy, Chicago: The Chicago University Press.

Calvo, Guillermo and Végh, Carlos, 1999, "Inflation Stabilization and BOP Crises in Developing Countries," In John Taylor and Michael Woodford, eds., Handbook of Macroeconomics, Volume C, North Holland.

Click, Reid, 1998, "Seigniorage in a Cross-Section of Countries," Journal of Money, Credit, and Banking 30, pp. 154-163.

Cukierman, Alex, Edwards, Sebastian, and Tabellini, Guido 1992, "Seignorage and Political Instability," The American Economic Review, Vol. 82, pp. 537-555.

De Haan, Jakob and Kooi, Willem, 2000, "Does Central Bank Independence Really Matter? New Evidence for Developing Countries Using a New Indicator," Journal of Banking and Finance, Vol. 24, pp. 643-64.

Dornbusch, Rudiger and Fischer, Stanley, 1993, "Moderate Inflation," The World Bank Economic Review, Vol.7, pp. 1-44.

Dornbusch, Rudiger, Sturzenegger, Federico, and Wolf, Holger, 1990, "Extreme Inflation: Dynamics and Stabilization," Brookings Papers on Economic Activity, Vol. 2, pp. 184. 
Fatás, Antonio and Rose, Andrew. 2001, "Do Monetary Handcuffs Restrain Leviathan? Fiscal Policy in Extreme Exchange Rate Regimes," Center for Economic Policy Research Discussion Paper 2692.

Fischer, Stanley and Orsmond, David, 2000, "Israeli Inflation from an International Perspective," International Monetary Fund, Working Paper 00/178.

Fischer, Stanley, Sahay, Ratna, and Végh, Carlos, 2000, "Modern Hyper - and High Inflations," Journal of Economic Literature, Forthcoming.

Franco, Gustavo, 1990, "Fiscal Reforms and Stabilization: Four Hyperinflation Cases Examined," The Economic Journal, 100, pp. 176-187.

Ghosh, Atish, Gulde, Anne-Marie, and Ostry, Jonathan. 1995. Does the Nominal Exchange Rate Regime Matter? "International Monetary Fund, Working Paper 95/121.

International Monetary Fund. 2001, World Economic Outlook, May 2001, Washington D.C.: International Monetary Fund.

King, Robert and Plosser, Charles, 1985, "Money, Deficits, and Inflation," Carnegie Rochester Conference Series on Public Policy, 22, pp. 147-196.

Lane, Philip, 1995, "Inflation in Open Economies," Journal of International Economics, 42, pp. $327-347$.

Levy-Yeyati, Eduardo and Sturzenegger, Federico, 2000, "Exchange Rate Regimes and Economic Performance," Universidad Torcuato Di Tella, Mimeo.

Ljungqvist, Lars and Sargent, Thomas, 2000, Recursive Macroeconomic Theory. Cambridge: The MIT Press.

Loungani, Prakash, and Swagel, Phillip, 2001, "Sources of Inflation in Developing Countries," IMF, Mimeo.

Metin, Kivilcim, 1998, "The Relationship Between Inflation and the Budget Deficit in Turkey," Journal of Business and Economic Statistics, 16, pp. 412-422.

Mitchell, Brian, 1998, International Historical Statistics, New York: Stockton Press.

Montiel, Peter, 1989. "An Empirical Analysis of High-Inflation Episodes in Argentina, Brazil, and Israel," International Monetary Fund Staff Papers, 36, pp. 527-549.

O'Connell, Paul G., 1998. “The Overvaluation of Purchasing Power Parity,” Journal of International Economics, 44, pp. 1-19. 
Pesaran, M. Hashem, 1997, "The Role of Economic Theory in Modelling the Long-run," Economic Journal, 107, pp. 178-191.

Pesaran, M. Hashem and Shin, Yongcheol 1998, "An Autoregressive Distributed Lag Modelling Approach to Cointegration Analysis," In Steinar Strom, ed., Econometrics and Economic Theory in the $20^{\text {th }}$ Century: The Ragnar Frisch Centennial Symposium, Cambridge: Cambridge University Press.

Pesaran, M. Hashem, Shin, Yongcheol, and Smith, Ron, 1999, "Pooled Estimation of LongRun Relationships in Dynamic Heterogeneous Panels," Journal of the American Statistical Association, 94, pp. 621-634.

Rodrik, Dani, 1991, "Premature Liberalization, Incomplete Stabilization: The Özal Decade in Turkey", In Michael Bruno, Stanley Fischer, Elhanan Helpman, and Nissan Liviatan, eds., Lessons of Economic Stabilization and Its Aftermath, Cambridge: The MIT Press.

Rodrik, Dani, 1998, "Why Do More Open Economies Have Bigger Governments?" Journal of Political Economy, Vol. 106, pp. 997-1032.

Romer, David, 1993, "Openness and Inflation: Theory and Evidence," Quarterly Journal of Economics, Vol.108, pp. 869-903.

Sargent, Thomas, 1982, "The Ends of Four Big Inflations," In Robert Hall, ed., Inflation, Causes, and Effects, Chicago: University of Chicago Press.

Sargent, Thomas and Wallace, Neil, 1981, "Some Unpleasant Monetarist Arithmetic," Federal Reserve Bank of Minneapolis Quarterly Review, Fall.

Tanzi, Vito, Blejer, Mario, and Tejeiro, Mario, 1993, "Effects of Inflation on Measurement of Fiscal Deficits: Conventional Versus Operational Measures," In Mario Blejer and Adrienne Cheasty, eds., How to Measure the Fiscal Deficit, Washington D.C.: International Monetary Fund

Tornell, Aaron and Velasco, Andrés, 2000, "Fixed versus Flexible Exchange Rates: Which Provides More Fiscal Discipline?," Journal of Monetary Economics, 45, pp. 399-436. 